Indonesian Journal of Medicine (2019), 4(3): 228-231

https://doi.org/10.26911/theijmed.2019.04.03.05

\title{
Factors Affecting Ankle Functional Scores at Spastic Diplegia Cerebral Palsy Patients that Have Been Performed Single Event Multi Level Surgery
}

\author{
Aryo Budiyogo Andryanto',2), Anung Budi Satriadi'), Mujaddid Idulhaq1) \\ ${ }^{1)}$ Orthopaedic and Traumatology, Prof. Dr. R Soeharso Orthopedic Hospital, Surakarta \\ ${ }^{2)}$ Faculty of Medicine, Universitas Sebelas Maret
}

\begin{abstract}
Background: Single Event Multi Level Surgery (SEMLS) is the treatment most often used to correct deformities and functional in children with Spastic Diplegic Cerebral Palsy. There is no research in Indonesia that assesses the ankle function in patients with Spastic CP Diplegic has done SEMLS. The purpose of this study was to determine the influence of age, gender and time period after surgery with functional ankle patients with CP Spastic Diplegic that has been done SEMLS in the RSO. Prof. Dr. R. Soeharso Surakarta (RSO).

Subjects and Method: This study was a cross sectional study in 43 patients (25 male and 18 female) patients with Spastic Cerebral Palsy Diplegia that has been done SEMLS in pediatric orthopedics clinic RSO. Prof.dr.R.Soeharso Surakarta at least 3 months postoperatively, since January $1^{\text {st }} 2013$ to December $31^{\text {st }} 2014$. We assessed ankle function using the Oxford Ankle Foot Questionnaire for Children. From the results of the questionnaire we value outcomes as a percentage and we regrouped into 4 groups: value of $91 \%-100 \%$ for excellent value, $81 \%-90 \%$ for good, $71 \%-80 \%$ for fair and if less than $70 \%$ for poor. Then we did impact assessment for age, sex and time of the postoperative with functional ankle score of patients with examination of linear regression model analysis.

Results: There were 52 patients with Spastic CP Diplegi have done SEMLS but only 43 patients who qualified the inclusion criteria, the youngest patient was 5 years old and the oldest 15 years old with a mean age of 8.3 years. From the 43 patients, 25 are men and 18 were women. Postoperative time with the fastest time of observation was 5 months and the longest was 26 months with a mean of 14.3 months postoperatively SEMLS. From the 43 patients there are 11 patients (25\%) function are excellent, 21 patients (49\%) are good, 8 patients (19\%) are fair, and $3(7 \%)$ are poor. Age factor significantly influence the functional ankle score $(\mathrm{p}=0.013)$ and postoperative time factors also significantly influence the functional score Ankle with $(\mathrm{p}=0.04)$. While gender has no effect on the functional ankle score $(\mathrm{p}=0.266)$.

Conclusion: Paediatri Orthopaedic clinic at RSO. Prof. Dr. R. Soeharso has succed treated patients with CP Spastic Diplegic that have performed SEMLS. Age and time of postoperative significantly influence the functional ankle score in patients with CP Spatik Diplegic that have been done SEMLS. While the sex of the patients had no effect on the functional ankle score in patients with CP Spastic Diplegic that have been done SEMLS.
\end{abstract}

Keywords: RSO Prof. Dr. R. Soeharso, CP Spastic Diplegic, SEMLS, Ankle Functional Score

\section{Correspondence:}

Aryo Budiyogo Andryanto. Student of Orthopaedic and Traumatology school of Medicine, Sebelas Maret University, Jl. Ir. Sutami 36 A, Surakarta 57126, Central Java.

\section{BACKGROUND}

Cerebral palsy (CP) is a brain disorder or damage to non-progressive that occurs in the growth process. Abnormalities or damage can occur during in utero (pre- natal), during the process of giving birth (prenatal), or after birth (postnatal). CP may result in disruption attitude (posture), motion control, impaired muscle strength is usually accompanied by neurologic dis- 
orders such as paralysis, spastic disorders of basal ganglia, cerebellum, and mental disorders (mental retardation) (Herring $\mathrm{J}$ (2014; Merlina et al., 2012; Mardiani, 2006).

In Indonesia, the prevalence of $\mathrm{CP}$ is estimated at around 1-5 per 1,000 live births (Mardiani, 2006). Men more than women. Often there is the first child. This is probably because the first birth have more frequent births jammed. The number of events was higher in infants of low birth weight and multiple births (Mardiani, 2006; Firth, 2013; Morrissy et al., 2006; Hamid, 2013; Moster et al., 2010).

Standard of care for management of gait dysfunction in children with spastic diplegia is a single event multilevel surgery (SEMLS) where all contractures and bone abnormalities are handled in one operation session (Saharso; 2006; Mcginley, 2011; Thomason et al., 2011; Barnet, 1952; Lawrence, 2001).

There has not been a study assessing the functional outcome of the ankle after SEMLS in Indonesia yet.

\begin{tabular}{l}
\hline \multicolumn{1}{c}{ SUBJECTS AND METHOD } \\
\hline 1. Study Design \\
This study is an observational cross-sectio- \\
nal review. This study was conducted at the \\
Paediatrics' Outpatient Department Prof. \\
Dr. dr. R. Soeharso RSO Surakarta from \\
January, 2013 to December, 2014.
\end{tabular}

\section{Population and Sample}

The population were all patients with Spastic diplegic Cerebral Palsy in Paediatric Clinic Prof. Dr. R. Soeharso RSO Surakarta that have been performed SEMLS.

The samples used were patients with Spastic Cerebral Palsy diplegic Spastic diplegic Cerebral Palsy in Paediatric Clinic Prof.Dr.R.Soeharso RSO Surakarta that have been performed SEMLS.

\section{Study Instrument}

All patients that have been performed SEMLS then evaluate the ankle functionale outcome with "The Oxford ankle foot questionnaire for children" (Doll et al., 2008). The outcome expressed as percentage values; If the percentage of $100 \%$ 91\%: excellent (special); 81-90\% is very good, $71-80$ is considered fair, less than $70 \%$ is considered poor.

\section{Data Analysis}

Multiple linear regression tests to determine the effect of age, gender and duration of post-operative evaluation with simultaneous treatment outcome.

\section{RESULTS}

From studies carried out from January 1 2013 until December 31, 2014 obtained 52 patients, 9 patients were excluded because of age did not fit and could not be reached. Forty-three (43) patients have been conducted interviews. The youngest patient was 5 years old and the oldest 15 years old with a mean age of 8.3 years. From the 43 patients, 25 are men and 18 were women. Postoperative time with the fastest time of observation was 5 months and the longest was 26 months with a mean of 14.3 months postoperatively SEMLS. From the 43 patients there are 11 patients (25\%) function are excellent, 21 patients (49\%) are good, 8 patients (19\%) are fair, and 3 (7\%) are poor. Age factor significantly influence the functional ankle score $(p=0.013)$ and postoperative time factors also significantly influence the functional score Ankle with ( $p$ $=0.04$ ). While gender has no effect on the functional ankle score $(p=0.266)$.

\section{DISCUSSION}

From this study, it was found that 11 patients (25.6\%) excellent results, 21 patients (48.8\%) were good, 8 patients (18.6\%) 
were fair, and 3 patients (7\%) were poor. This illustrates that pediatric orthopedics clinic RSO quite successful in treating patients Diplegik Spastic CP has done SEMLS. This is in line with some of the research that has been done before. One is the research that has been conducted by Thomas Dreher and colleagues in 2012 which found that the long-term evaluation found a nice run function in patients with Spastic CP Diplegik conducted as part of the gastrocnemius resection as a part of SEMLS (Thomas, 2012).

According to Jarvis in 2005 mentioned that the ratio of boys - men who suffer from cerebral palsy more when compared with patients perempuan Jarvis (2005). This study also found that the ratio of male patients - male more than female patients, i.e from 43 patients, 25 ( $58 \%$ ) were male female and 18 (42\%) were female.

According to research conducted by Marvin Svehlik June 2011 states that currently do SEMLS age affects the outcome of long-term therapy. In older children obtained better results than the younger children in the study period panjang Svehlik (2011). It is also found in our penilitian where, from 43 patients who became the subject of research with the youngest age of 5 years and a maximum of 15 years with a mean age - average age of 8.3 years showed that the age factor when done SEMLS significantly affect the results of functional ankle score in patients with Spastic CP Diplegik has done SEMLS with $\mathrm{p}$ $=0.013$.

In the study conducted by Ki Hyuk Sung and colleagues found that longterm outcomes in patients with Spastic CP Diplegik has done SEMLS 10 years better than patients who have done SEMLS 1 tahun Sung (2012). In this study it was found that the length of post-operative evaluation of influence significantly affect the function of the ankle with a value of $p=$ 0.004. In this study showed that the longer the duration of post-operative evaluation of a child, the better the function of the ankle.

In the study conducted by Jarvis and friends - friends in 2005, it was found that the gender effect on the severity of the patient's functional and Cerebral Palsy Jarvis (2005). Chounti and friends - friends get that boy - boy with Cerebral Palsy has the severity and risk weight when compared with children of women who suffer from Cerebral Palsy (Sung, 2012). But we did found that gender did not affect the functional ankle score in patients with Spastic Diplegik CP that has been done SEMLS, with $\mathrm{p}=0.266$.

Pediatric Orthopedic Clinic successfully treating patients with CP Spastic Diplegi SEMLS method based on its functional ankle. The age of patients when surgery significantly affect the functional ankle on Spastic Diplegik CP patients who were treated with the method SEMLS.

The length of time the evaluation of postoperative significant effect on the patient's functional ankle at patients with Spastic Diplegic CP has done SEMLS. The longer the duration of post-operative evaluation of ankle function better Spastic Diplegic CP patients that have been performed SEMLS.

Sex of the patients had no effect on functional outcome in patients with Spastic Diplegik CP who were treated with the method SEMLS.

\section{AUTHORS CONTRIBUTION}

Aryo Budiyogo Andryanto collected data and wrote the manuscript. Anung Budi Satriadi examined data analysis the data. Mujaddid Idulhaq suggested the discussion.

\section{CONFLICT OF INTEREST}

There was no conflict of interest in this study. 


\section{FUNDING AND SPONSORSHIP}

This study used the authors' independent fund.

\section{ACKNOWLEDGEMENT}

We would like to thank to Paediatrics' Outpatient Department Prof. Dr. dr. R. Soeharso RSO Surakarta for giving permission to take the data.

\section{REFERENCE}

Barnet H (1952). Orthopedic Surgery In Cerebral Palsy. JAMA. 150(14): 13961398.

Chounti A, Hägglund G, Wagner P, Westbom L (2013). Sex differences in cerebral palsy incidence and functional ability: a total population study. Acta Paediatrica.

Doll HA, Fitzpatrick RA, Morris C, Theologis T, Wainwright (2008). The Oxford Ankle Foot Questionnaire For Children Scaling, Reliability And Validity. J Bone Joint Surg [Br]. 90-B: 1451-6.

Firth GB (2013). Multilevel Surgery for Equinus Gait in Children with Spastic Diplegic Cerebral Palsy. J Bone Joint Surg Am. 95: 931-8.

Hamid A (2013). Cerebral Palsy. Medscape. Retrieved from http://emedicine.med scape.com/article/11795550verview\#a w2aab6b2b4aa.

Herring J (2014). Tachdjian's Pediatric Orthopaedics, $5^{\text {th }}$ Edition, Saunders Elsevier.

Jarvis S (2005). Case gender and severity in cerebral palsy varies with intrauterine growth. Arch Dis Child, 90: 474-479.

Lawrence A (2001). Chapman's Orthopaedic Surgery: 3rd Edition. Lippincott Williams \& Wilkins. 177: 4886-4887.
Mardiani E (2006). Faktor-faktor risiko prenatal dan perinatal kejadian cerebral palsy (Studi kasus di YPAC Semarang). Universitas Diponegoro Semarang.

Mcginley JL (2011). Single-event multilevel surgery for children with cerebral palsy:a systematic review. Developmental Medicine \& Child Neurology. Mac Keith Press.

Merlina M, Kusnadi Y, Artati (2012). Prospek Terapi Sel Punca untuk Cerebral Palsy. CDK-198/ 39(10). Jakarta.

Morrissy, Raymond T, Weinstein, Stuart L, Lovell Winter's (2006). Pediatric Orthopaedics, 6th Edition. Lippincott Williams \& Wilkins.

Moster D, Wilcox AJ, Vollset SE, Markestad T, Lie RT (2010). Cerebral palsy among term and postterm births. JAMA, 304(9): 976-82.

Saharso D (2006). Cerebral Palsy Diagnosis dan Tatalaksana. FK UNAIR.

Sung KH (2012). Long term outcome of single event multilevel surgery in spastic diplegia with flexed knee gait. Elsevier.

Svehlik M (2011). The influence of age at single-event multilevel surgery on outcome in children with cerebral palsy who walk with flexed knee gait Developmental medicine and neurology. Austria.

Thomas D (2012). Long-Term Results After Gastrocnemius-Soleus Intramuscular Aponeurotic Recession as a Part of Multilevel Surgery in Spastic Diplegic Cerebral Palsy. J Bone Joint Surg Am. 94: 627-37.

Thomason P, Baker R, Dodd K (2011). Single-Event Multilevel Surgery in Children with Spastic Diplegia. J Bone Joint Surg Am. 93: 451-60. 